\title{
Keefektifan Penggunaan Media Gambar Berseri dalam Keterampilan Menulis Kalimat Sederhana Bahasa Jerman Siswa
}

Yatri Gilli' dan Ambo Dalle ${ }^{2}$

Fakultas Bahasa dan Sastra,Universitas Negeri Makassar ${ }^{1,2}$

Email : yatrigilli@gmail.com ${ }^{1}$

\section{E-ISSN : 2579-4574}

P-ISSN : 2549-7359

\begin{abstract}
The purpose of this study was to obtain data related the effectiveness of serial image media in increasing students' simple German sentence writing skills. The design of this study is true Experimental Design (Pretest-Postest Control Group Design). Samples are selected randomly. Data were analyzed using t-test. The results of the analysis show that $\mathrm{t}$-count $5.52>t$ table 2.005 at a significant level of 0.05 . The results showed that serial image media were effective in increasing students' simple German sentence writing skills.
\end{abstract}

Keywords: Effectiveness, Radiant Image Media, Writing Skills.

\section{https://ojs.unm.ac.id/eralingua}

\section{PENDAHULUAN}

Bahasa adalah alat komunikasi yang digunakan oleh manusia untuk menyampaikan pikiran dan perasaan secara lisan maupun tulisan. Bahasa juga sangat diperlukan dalam dunia pendidikan sebagai pengantar informasi dalam pembelajaran, sehingga manusia memerlukan bahasa setiap saat. Salah satu media yang dapat menunjang pencapaian tujuan pembelajaran adalah penggunaan media gambar berseri. Penggunaan media gambar berseri dalam pembelajaran mampu meningkatkan kemampuan siswa untuk berpikir kreatif dalam menulis, pembelajaran akan lebih menarik dan tidak membosankan. Pembelajaran merupakan suatu kegiatan yang melibatkan guru dan siswa. Di dalam kegiatan pembelajaran diperlukan media ataupun pendekatan yang tepat, sehingga peserta didik dapat memahami dan memeroleh informasi dari materi yang diajarkan (Yusri dkk., 2018; Romadloni dkk., 2017).

Menurut Kustandi (2011:10) media pembelajaran adalah alat yang dapat membantu proses belajar mengajar dan berfungsi untuk memperjelas makna pesan yang akan disampaikan, sehingga dapat mencapai tujuan pembelajaran dengan baik dan sempurna. Selanjutnya Arsyad (2017:4) mengemukakan bahwa media pembelajaran adalah segala sesuatu yang membawa pesan-pesan atau informasi yang memiliki tujuan instruksional dan mengandung maksud-maksud pelajaran. Gambar merupakan media visual yang dapat diamati oleh setiap orang yang memandangnya. 
Menurut Sadiman (2012:29) gambar berseri adalah rangkaian gambar yang terdiri atas dua gambar atau lebih yang merupakan satu kesatuan cerita. Selanjutnya, Danim dalam Haerani (2013:25) menyatakan bahwa media gambar merupakan seperangkat alat bantu atau pelengkap yang digunakan oleh guru atau pendidik dalam rangka berkomunikasi dengan siswa.

Keterampilan menulis merupakan salah satu aspek keterampilan berbahasa yang penting dalam kehidupan manusia. Melalui kegiatan menulis seseorang dapat memberitahu menyampaikan informasi (pesan), serta menuangkan ide tau gagasan. Menurut Byrne dalam Saddhono dan Slamet (2014:163) keterampilan menulis adalah kemampuan menuangkan buah pikiran ke dalam bahasa tulis melalui kalimat-kalimat yang dirangkai secara utuh, lengkap dan jelas sehingga buah pikiran tersebut dapat dikomunikasikan kepada pembaca dengan berhasil. Sedangkan Tarigan (2013:3) mengemukakan bahwa keterampilan menulis merupakan suatu keterampilan berbahasa yang digunakan untuk berkomunikasi secara tidak langsung, tidak secara tatap muka dengan orang lain.

Kalimat merupakan satuan bahasa berupa kata atau rangkaian kata yang dapat berdiri sendiri dan menyatakan makna yang lengkap. Kalimat sekurang-kurangnya harus memiliki subjek $(S)$ dan predikat $(P)$. Penelitian ini fokus mengkaji hasil tes kalimat sederhana mahasiswa, serta menawarkan model media gambar berseri untuk meningkatkan kemampuan mahasiswa dalam menulis kalimat sederhana.

\section{METODE PENELITIAN}

Penelitian ini terdiri dari dua variabel yakni variabel bebas $(X)$ dan variabel terikat (Y). Variabel bebas adalah penggunaan media gambar berseri, sedangkan variabel terikat adalah keterampilan menulis kalimat sederhana bahasa Jerman. Desain penelitian yang digunakan dalam penelitian ini adalah True Experimental Design dengan bentuk Pretest-Posttest Control Group Design. Penggunaan media gambar berseri yang sesuai dengan tema keluarga. Penggunaan media gambar berseri dapat mengembangkan daya imajinasi siswa, melatih kecermatan dan ketelitian siswa dalam memperhatikan sesuatu.

Populasi dalam penelitian ini adalah siswa kelas XI SMA Katolik Makale yang terdiri dari 5 kelas dengan jumlah siswa 147 siswa. Sampel yang digunakan adalah kelas XI IPA 1 yang berjumlah 28 orang sebagai kelas kontrol dan siswa kelas XI IPA 3 yang berjumlah 28 orang sebagai kelas eksperimen yang dipilih secara acak (Random Sampling). Dengan demikian sampel dalam penelitian ini adalah 56 orang. Teknik pengumpulan data dalam penelitian ini dilakukan dengan beberapa tahap, antara lain: (1) Tes awal (Pre-test); (2) Perlakuan (Treatment); (3) Tes akhir (Post-test). Penilaian keterampilan menulis yang digunakan merujuk pada penilaian yang dikemukakan oleh Djiwandono (2011: 68) dan penilaian hasil keseluruhan tes mengacu pada pedoman yang digunakan guru mengkonversi skor-skor yang diperoleh ke nilai seratus dengan rumus: 


$$
\text { Nilai }=\frac{\text { skor yang diperoleh }}{\text { jumlah skor maksimal }} \times 100
$$

(Purwanto, 2013: 102)

Data yang diperoleh dianalisis menggunakan analisis statistic deskriptif dan inferensial untuk menguji hipotesis penelitian dengan menggunakan uji-t. Namun sebelumnya, terlebih dahulu dilakukan uji normalitas dengan menggunakan tabel ZScore, Chi-kuadrat dan uji homogenitas dengan menggunakan uji F (Fischer), tetapi sebelum menentukan uji normalitas, uji homogenitas data, maupun uji hipotesis terlebih dahulu tentukan nilai rata-rata (Mean), simpang baku dan varians.

\section{HASIL DAN PEMBAHASAN}

Proses pembelajaran dalam penelitian ini dilaksanakan empat kali pertemuan. Sebelum melaksanakan proses pembelajaran, kedua kelas yakni kelas eksperimen dan kelas kontrol terlebih dahulu diberikan tes awal (Pre-test) dengan soal yang sama. Setelah kedua kelas diberikan Pre-test, kedua kelas kemudian diajar dengan media yang berbeda. Pada kelas eksperimen siswa diajar dengan menggunakan media gambar berseri dalam keterampilan menulis kalimat sederhana bahasa Jerman, sedangkan pada kelas kontrol siswa diajar dengan metode konvensional atau tidak menggunakan gambar berseri. Setelah proses pembelajaran selama 4 kali pertemuan kedua kelas kembali diberikan tes akhir (Post-test). Pre-test yang diberikan kepada siswa dalam keterampilan menulis kalimat sederhana bahasa Jerman pada kelas eksperimen (XI IPA 3) menunjukkan bahwa nilai rata-rata (Mean) yang diperoleh adalah 48,89 dengan hasil analisis menunjukkan bahwa 12 siswa (42,85\%) memeroleh nilai terendah yaitu 42 dan 1 siswa (3,57\%) memeroleh nilai tertinggi yaitu 75 . Sedangkan pada kelas kontrol (XI IPA 1) memeroleh nilai rata-rata pre-test sebesar 40,85 dengan hasil analisis data menunjukkan bahwa 1 siswa (3,57\%) memeroleh nilai terendah yaitu 25 dan 1 siswa (3,57\%) memeroleh nilai tertinggi yaitu 58. Rendahnya perolehan nilai pada kedua kelas dikarenakan kurangnya kosakata yang dimiliki siswa serta kurangnya penguasaan tata bahasa siswa dalam menulis kalimat sederhana bahasa Jerman.

Hasil dari nilai pre-test tersebut kemudian diuji dengan menggunakan uji normalitas dan uji homogenitas. Hasil analisis uji normalitas menunjukkan bahwa nilai yang diperoleh pada kelas eksperimen (XI IPA 3) dan kelas kontrol (XI IPA 1) masingmasing sebesar -22,33 dan -119,59. Hasil tersebut kemudian dibandingkan dengan menggunakan tabel Chi-kuadrat ( $d \mathrm{k}=5$, taraf signifikansi 0,05) sebesar 11,07 menunjukkan bahwa $X^{2}$ hitung $(-22,33)<X^{2}$ tabel $(11,07)$ dan $X^{2}$ hitung $(-119,59)<X^{2}$ tabel $(11,07)$, sehingga distribusi data pre-test pada kelas eksperimen dan kelas kontrol dinyatakan normal, artinya tes yang diberikan sesuai dengan kemampuan siswa. Sedangkan hasil uji homogenitas menunjukkan bahwa nilai $F_{\text {hitung }}$ pada kelas eksperimen dan kelas kontrol adalah 1,26. Hasil tersebut kemudian dibandingkan dengan $F_{\text {tabel }}(\mathrm{dk}=5$, taraf signifikansi 0,05) sebesar 5,050 menunjukkan bahwa Fhitung lebih kecil daripada $F_{\text {tabel }}$ 
( $\left.F_{\text {hitung }}(1,26)<F_{\text {tabel }}(5,050)\right)$, sehingga dapat disimpulkan bahwa kedua sampel pada kelas eksperimen dan kelas kontrol dinyatakan homogen.

Selanjutnya Post-test yang diberikan kepada siswa dalam keterampilan menulis kalimat sederhana bahasa Jerman menunjukkan bahwa nilai rata-rata pada kelas eksperimen (XI IPA 3) adalah 70,14 dengan hasil analisis menunjukkan bahwa 10 siswa (35,71\%) memroleh nilai terendah yaitu 58 dan 2 siswa (7,14\%) memeroleh nilai tertinggi yaitu 92. Pada kelas kontrol diperoleh nilai rata-rata post-test sebesar 56,82 dengan hasil analisis menunjukkan bahwa 3 siswa $(10,71 \%)$ memeroleh nilai terendah yaitu 42 dan 2 siswa (7,14\%) memeroleh nilai tertinggi yaitu 75. Hal tersebut menunjukkan bahwa pada kelas eksperimen siswa mampu meningkatkan keterampilan menulis kalimat sederhana bahasa Jerman dengan penggunaan kosakata dan tata bahasa yang baik. Sedangkan pada kelas kontrol yang belajar tanpa menggunakan media gambar berseri tidak mengalami peningkatan yang begitu signifikan, karena masih kurangnya pembendaharaan kosakata yang dimiliki siswa.

Hasil post-test siswa kemudian dilakukan pengujian hipotesis dengan menggunakan uji-t untuk mengetahui hasil akhir dari penelitian ini, yaitu ada tidaknya perbedaan keterampilan menulis kalimat sederhana bahasa Jerman siswa pada kelas eksperimen dan kelas kontrol. Pada hasil perhitungan diperoleh data bahwa thitung sebesar 5,52. Hasil tersebut kemudian dibandingkan dengan ttabel pada taraf signifikansi $5 \%(0,05)$ dan $\mathrm{df}=56$ sebesar 2,005. Maka dapat disimpulkan bahwa thitung lebih besar daripada $t_{\text {tabel, yakni thitung }}(5,52)>t_{\text {tabel }}$ (2,005). Dengan demikian $\mathrm{H}_{1}$ yang berbunyi: Penggunaan media gambar berseri efektif dalam keterampilan menulis kalimat sederhana bahasa Jerman siswa kelas XI SMA Katolik Makale dinyatakan diterima. Sedangkan $\mathrm{H}_{0}$ yang berbunyi: Penggunaan media gambar berseri tidak efektif dalam keterampilan menulis kalimat sederhana siswa kelas XI SMA Katolik Makale dinyatakan ditolak.

Berdasarkan uraian di atas, dapat disimpulkan bahwa keefektifan penggunaan media gambar berseri dalam keterampilan menulis kalimat sederhana bahasa Jerman siswa kelas XI SMA Katolik Makale dinyatakan efektif digunakan dalam pembelajaran bahasa Jerman. Temuan penelitian ini didukung oleh teori Denim dalam Haerani (2013: 25) yang mengemukakan bahwa media gambar merupakan seperangkat alat bantu atau pelengkap yang digunakan oleh guru atau pendidik dalam rangka berkomunikasi dengan siswa. Media gambar berseri dapat digunakan untuk mempermudah siswa menyusun kata-kata menjadi sebuah kalimat, selain itu siswa kreatif dalam menulis kalimat bahasa Jerman.

\section{KESIMPULAN}

Berdasarkan hasil analisis data yang telah diuraikan sebelumnya, dapat disimpulkan bahwa penggunaan media gambar berseri efektif dalam keterampilan menulis kalimat sederhana bahasa Jerman siswa kelas XI SMA Katolik Makale. Hal tersebut dibuktikan melalui hasil pengujian hipotesis dengan menggunakan uji-t terhadap nilai post-test siswa, yaitu $t_{\text {hitung }}=5,52>t_{\text {tabel }}=2,005$ pada taraf signifikan 
0,05. Hal ini menunjukkan bahwa ada perbedaan yang signifikan antara penggunaan media gambar berseri dengan metode pembelajaran konvensional. Hasil analisis data tentang penggunaan media gambar berseri dalam keterampilan menulis kalimat sederhana bahasa Jerman siswa kelas XI SMA Katolik Makale pada kelas eksperimen menunjukkan bahwa nilai rata-rata pre-test siswa adalah 48,89 dengan nilai tertinggi 75 dan nilai terendah 42. Sedangkan hasil post-test pada kelas eksperimen menunjukkan bahwa nilai-rata siswa adalah 70,14 dengan nilai tertinggi 92 dan nilai terendah 58 . Selanjutnya hasil analisis data penggunaan media gambar berseri dalam keterampilan menulis kalimat sederhana bahasa Jerman siswa kelas XI SMA Katolik Makale pada kelas kontrol menunjukkan bahwa nilai rata-rata pre-test siswa adalah 40,85 dengan nilai tertinggi 58 dan nilai terendah 25 . Sedangkan nilai rata-rata post-test siswa adalah 56,82 dengan nilai tertinggi 75 dan nilai terendah 42.

\section{DAFTAR PUSTAKA}

Arsyad, Azhar. (2017). Media Pembelajaran. Jakarta: Rajawali Pers.

Arsyad, Azhar. (1997). Media Pembelajaran. Jakarta: PT Rajagrafindo Persada.

Djiwandono, Soenardi. (2011). Tes Bahasa :Pegangan Bagi Pengajar Bahasa. Edisi 2. Jakarta: Indeks.

Haerani. (2013). Kemampuan Menulis Kalimat Sederhana Bahasa Jerman Melalui Media Gambar Siswa Kelas XI SMA Negeri 1 Bontonompo Kabupaten Gowa. Skripsi. Makassar: Universitas Negeri Makassar.

Romadloni, A., \& Mantasiah, R. Intercultural approach in foreign language learning to improve students' motivation. Senior Editors, 61.

Saddhono, Kundharu dan Y. Slamet. (2014). Pembelajaran Berbahasa Indonesia Teori dan Aplikasi. Yogyakarta: Graha Ilmu.

Sadiman, Arief. (2012). Media pendidikan. Jakarta: Rajawali

Tarigan, Henry Guntur. (2013). Menulis Sebagai Keterampilan Berbahasa. Bandung: Angkasa.

Yusri, Y., Mantasiah, R., \& Jufri, J. (2018). The Use Of Two Stay Two Stray Model in English Teaching to Increase Student's Learning Outcome. Journal Of Advanced English Studies, 1(1), 39-43. 